\title{
A Case of Myeloid Sarcoma in the Nasal Cavity Occurred in the Patient with Leukemic Transformation in Myelodysplastic Syndrome
}

\author{
Dong Hoo Lee ${ }^{1}$, Sung Yool Park ${ }^{1}$, Ha Young Park ${ }^{2}$, and Seong Kook Park ${ }^{1}$ (D) \\ ${ }^{1}$ Departments of Otorhinolaryngology-Head and Neck Surgery, ${ }^{2}$ Pathology, Busan Paik Hospital, Inje University College of Medicine, \\ Busan, Korea
}

\section{골수이형성 증후군의 백혈병성 변화 환자에서 발생한 비강의 골수성 육종 1 예 \\ 이동후 ${ }^{1} \cdot$ 박성율 $^{1} \cdot$ 박하영 ${ }^{2} \cdot$ 박성국 \\ 인제대학교 의과대학 부산백병원 이비인후-두경부외과학교실, ${ }^{1}$ 병리학교실 ${ }^{2}$}

\author{
Received January 6, 2019 \\ Revised April 1,2019 \\ Accepted April 9, 2019 \\ Address for correspondence \\ Seong Kook Park, MD \\ Department of Otorhinolaryngology- \\ Head and Neck Surgery, \\ Busan Paik Hospital, \\ Inje University College of Medicine, \\ 75 Bokji-ro, Busanjin-gu, \\ Busan 47392, Korea \\ Tel $+82-51-890-6379$ \\ Fax $+82-51-892-3831$
}

E-mail sinus4@paik.ac.kr

\begin{abstract}
Myeloid sarcoma is characterized by the presence of myeloid blasts at an extramedullar site that disrupts the normal architecture of the organ. Many of these cases are associated with acute myeloid leukemia, chronic myeloid leukemia, myelodysplastic syndrome, or occur in de novo. It occurs most commonly in skin, lymph node, gastrointestinal tract, bone, soft tissue but, rarely in head and neck; especially in nasal cavity. Therefore, it is often misdiagnosed as a different disease: most commonly as lymphoma. Here we report a rare case of myeloid sarcoma in the nasal cavity that occurred in a patient with leukemic transformation with myelodysplastic syndrome, provided with literature review.
\end{abstract}

Korean J Otorhinolaryngol-Head Neck Surg 2020;63(2):81-4

Key Words Myelodysplastic syndrome $\cdot$ Myeloid sarcoma $\cdot$ Nasal cavity.

\section{서 론}

골수성 육종(myeloid sarcoma)은 골수모세포가 골수 외 조직에 침범하여 정상 조직의 구조를 파괴하는 특징을 가진 질환으로 흔히 피부, 림프절, 위장관, 빼, 연조직에서 발생하 며 비강에서는 매우 드물어 림프종으로 오진되기 쉽다.)

골수성 육종은 급성 골수성 백혈병, 만성 골수성 백혈병, 골수이형성 증후군과 관련되어 발생하며 ${ }^{1}$ 특히, 급성 백혈병 환자의 2 8\%에서 발생하고 이 중 15 35\%에서는 급성 백혈 병과 동시에 발견되며, $25 \%$ 에서는 급성 골수성 백혈병에 선 행하여 발생, 50\%에서는 급성 골수성 백혈병 진단 후 발생

This is an Open Access article distributed under the terms of the Creative Commons Attribution Non-Commercial License (https://creativecommons.org/licenses/by-nc/4.0) which permits unrestricted non-commercial use, distribution, and reproduction in any medium, provided the original work is properly cited.
한다. 이에 반해 골수이형성 증후군과 연관되어 발생한 경우 의 역학 및 빈도는 잘 알려져 있지 않다. ${ }^{2)}$ 국내에서는 비강의 골수성 육종 중 급성 골수성 백혈병과 동시에 발생한 증례 1 예,, 원발성으로 발생한 증례 2예,5)가 있으나 골수이형성 증 후군과 관련되어 발생한 경우는 보고된 바가 없다.

저자들은 골수이형성 증후군의 백혈병성 변화를 보이는 51 세 여자 환자에서 발생한 비강의 골수성 육종을 경험하였 기에 문헌고찰과 함께 보고하는 바이다.

\section{증 례}

51 세 여자 환자가 2개월 전부터 시작되어 점차 심해지는 양측 코막힘을 주소로 내원하였다. 환자는 류마티스 관절염, 고혈압, 고지혈증, 척추관 협착증, 자궁 근종이 있었으며 내 
원 2년 전 골수이형성 증후군, 골수증식성 질환, 골수섬유증 으로 진단되었고 내원 2개월 전 범혈구감소증의 악화, 말초 혈액 도말 검사에서 미성숙세포가 보여 시행한 골수 검사에 서는 백혈병성 변화를 보였지만 급성 골수성 백혈병의 진단 기준에 미치지 못하여 향후 골수 검사를 재시행하기로 하고 수혈 등의 대증적 치료를 하며 추적 관찰 중이었다. 환자의 전 신적 상태는 쇠약하였고, 몸통에는 2개월 전부터 나타난 자 색의 홍반성 결절이 있었다. 비내시경 검사에서는 불규칙한 경계의 표면과 비교적 단단한 종물이 양측 전비강을 완전히 막고 있는 소견이 관찰되었다. 우측 비강에서는 종물이 비중 격에서부터 팽윤되어 있었고, 좌측 비강에서는 비중격, 비강 저, 비강 외측 전반부에서 종물이 형성되어 있었다(Fig. 1). 내 원 당시 범혈구감소증은 이전보다 호전을 보였지만(백혈구 $1890 / \mu \mathrm{L}$, 혈색소 $8.0 \mathrm{~g} / \mathrm{dL}$, 혈소판 $136000 / \mu \mathrm{L}$ ) 말초 혈액 도 말 검사에서 미성숙세포가 $3 \%$ 로 관찰되었다. 비부비동 전산 화단층촬영에서는 비중격, 양측 사골동의 연조직 음영을 보 이는 종양이 보였고, 양측 상악동의 점막의 비후가 관찰 되었 으나 골미란은 명확하지 않았다(Fig. 2).

환자의 과거력, 비내시경 및 영상학적 검사 소견을 토대로 악성종양, 그 중에서 림프종의 가능성을 염두에 두었고 외래 에서 내시경을 이용한 조직 검사를 좌측 비강의 비중격, 비강 저부에서 시행하였으며 같은 시기에 피부과에서 몸통의 자 색의 홍반성 결절에 대한 조직 검사를 시행하였다.

비강 조직 검사에서 정상 비강 조직의 파괴를 동반하는 종 양세포의 침윤, 호산성의 세포질을 가지며, 세포의 핵은 나선 형의 핵막을 가지며 분산된 염색질과 눈에 띄지 않는 핵소체 의 소견을 보였으며 면역조직화학 검사에서는 $\mathrm{CD} 34$, myelo-

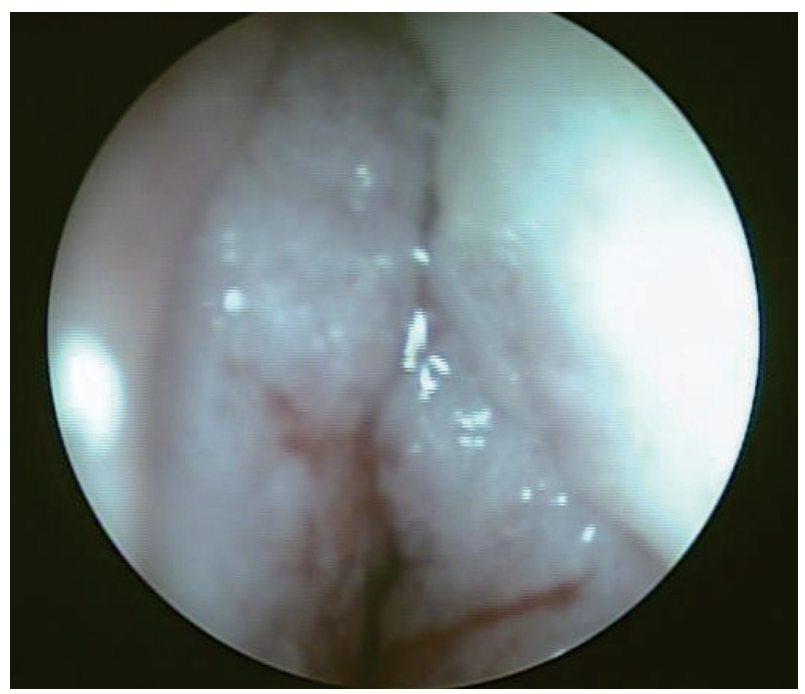

Fig. 1. Nasal endoscopic photograph. Left nasal cavity, around nasal valve. The mass with irregular surface was involving nasal septum, nasal floor, lateral wall.
peroxidase(MPO), c-kit, lysozyme 양성 소견을 보였으며 CD3, CD20, Epstein-Barr virus by in situ hybridization (EBV-ISH) 음성 소견을 보였다(Fig. 3). 피부의 홍반성 결절 에서도 $\mathrm{MPO}, \mathrm{CD} 34, \mathrm{c}-\mathrm{kit}$ 양성 소견, $\mathrm{CD} 3, \mathrm{CD} 20, \mathrm{CD} 30$, EBV-ISH 음성 소견이 나와 비강 및 피부의 골수성 육종으 로 진단되었다.

이에 따라 골수이형성증의 백혈병성 변화를 보였던 골수 상태의 변화를 파악하기 위해 혈액도말 검사 및 골수 검사를 재시행하였으나 이전과 같이 골수이형성증의 백혈병성 변화 를 보였지만 급성 골수성 백혈병의 진단 기준에는 미치지 못 하였다.

위의 결과들로, 골수이형성 증후군의 백혈병성 변화와 동 반된 비강 및 부비동, 피부의 골수성 육종으로 최종 진단하였 고 일차적 치료를 위해 idarubicine( $12 \mathrm{mg} / \mathrm{m}^{2}, 3$ 일), cytarabine(200 mg/m², 7일)의 항암화학요법을 계획하였다. 항암
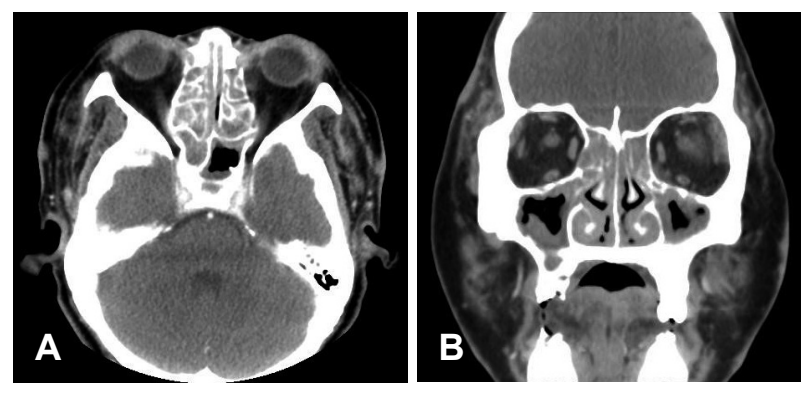

Fig. 2. Contrast enhanced paranasal sinus CT scans. CT showed a soft tissue density in both nasal septum and both ethmoid sinuses and mucosal thickening in both maxillary sinuses. Bone erosion around the mass was not obvious: axial (A) and coronal (B) images.
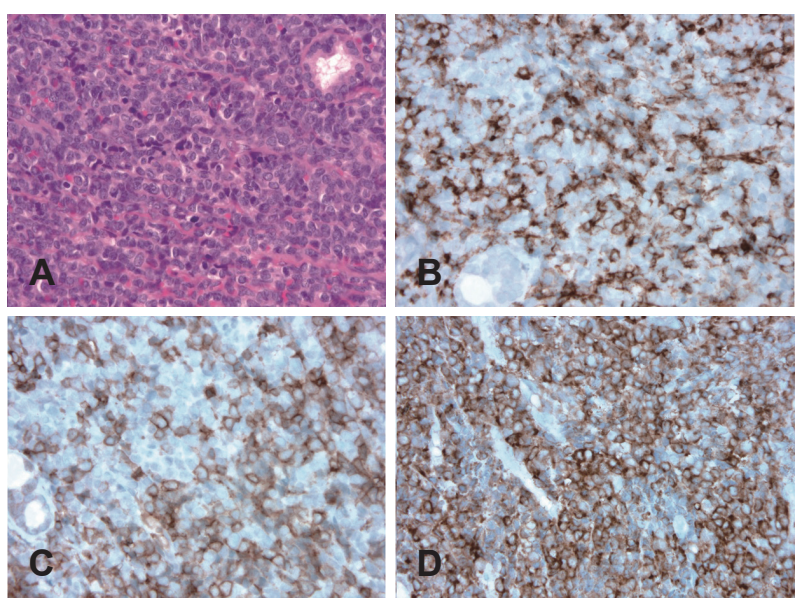

Fig. 3. Pathologic features of myeloid sarcoma. Biopsy and immunohistochemistry. Nuclei of tumor cells show convoluted membrane with dispersed chromatin and inconspicuous nucleoli. Tumor cells have eosinophilic cytoplasm (A: hematoxylin and eosin staining, $\times 400$ ). Neoplastic cells are positive for CD34 (B: immunohistochemical staining, $\times 400)$, kit (C: immunohistochemical staining, $\times 400$ ), and lysozyme (D: immunohistochemical staining, $\times 400)$. 
치료 6일째 호중구 감소를 동반한 설사 및 고열이 발생하였고 다음날 혈압이 저하되며 혈액배양에서 extended-spectrum beta-lactamses 양성 escherichia coli가 검출되어 패혈성 쇼 크로 광범위 항생제, 지속적신대체요법 등으로 치료하였으나 결국 다발성 장기부전으로 사망하였다.

\section{고 찰}

골수성 육종은 골수모세포로 이루어져 골수 외 부위에 발 생한 종양으로, 단순한 백혈병세포의 조직 침윤이 아니라 정 상 조직 구조의 소실을 동반하며, ${ }^{6}$ 골수 외 침범에 대한 병인 은 정확히 밝혀진 것은 없으나 비정상적인 백혈구의 회귀 신 호(homing signal)와 연관되며 구체적으로 B2 integrins와 matrix metalloproteinase 9로 이루어진 초분자 복합체가 백 혈병 세포의 세포 주위 단백분해 및 세포 이동에 관여한다고 한다고 생각된다. ${ }^{7}$

골수성 육종은 인체 내 어디에서도 발생할 수 있으나 두경 부에서의 발생은 드물며 특히 비강 및 부비동에서의 발생은 매우 드물어 현재까지 10예의 국외의 증례 보고가 이루어졌 다. ${ }^{1,2,89)}$ 증상은 종양의 발생 부위 및 크기에 따라 다양하나 대부분 비특이적인 경우가 많아 증상으로는 진단이 어렵다. ${ }^{1)}$ 비강 및 부비동에서는 코막힘이 가장 흔한 증상이며, 종양의 크기에 따라 급, 만성 부비동염이 합병될 수 있으며 화농성 콧물, 후비루, 두통 및 안면 부종 또는 압박감, 안와를 침범 할 경우 안구 돌출증, 시각 장애가 발생할 수 있다. ${ }^{899}$ 본 증 례의 경우 점진적인 양측 코막힘, 안면 압박감을 호소하였으 나 화농성 콧물, 후비루는 없었다.

많은 경우에서 골수성 육종은 다음과 같은 4가지 상황에 서 발생한다. 급성 골수성 백혈병을 진단받은 환자에게서 발 생하는 경우, 만성 골수성 백혈병의 급성기 전환(blast crisis) 환자에게 발생하는 경우, 골수이형성 증후군의 백혈병성 변 화 환자에게 발생하는 경우, 그리고 이러한 질환들의 명백한 증거 없이 원발성으로 발생하는 경우가 있다. ${ }^{2)}$

영상학적 소견은 비특이적으로 다른 종양성 병변과 감별 이 힘들지만, 일반적으로 컴퓨터전산화단층촬영에서 주변과 잘 경계지어지며 부드럽고 균질하게 조영증강되며 주변의 골 침범 시 융해성으로 나타나는 특징을 가지고 있다. ${ }^{10)}$ 주된 진 단법으로는 조직 병리 검사, 면역조직 화학 검사가 있으며 조 직 검사상 골수모세포, 중성구, 중성구계 전구세포들이 혼재 되어 있고 이들 세포들은 특징으로 높은 핵/세포질 비율을 보 이는 둥근 세포, 적은 세포질, 세포질에 호산구성 과립을 보 이는 세포들의 잦은 유사분열을 보인다.) 이러한 조직 검사 소 견은 다른 원형소세포종양(small round cell tumor)들을 감
별해야 하며 이를 위해서는 면역조직 화학 검사가 필요하다. ${ }^{1,8}$

구체적인 면역조직 화학 검사 항목들에는 $\mathrm{CD} 68 / \mathrm{KP} 1, \mathrm{MPO}$, CD43, CD117 또는 c-kit, CD99, CD68/PGM1, lysozyme, CD34, terminal deoxynucleotidyl transferase, CD56, CD30, glycophorin, $\mathrm{CD} 4$ 등이 있다. ${ }^{2}$ 골수성 육종에서 골수성 분화 의 표지자로는 $\mathrm{CD} 13, \mathrm{CD} 33, \mathrm{CD} 117$ 또는 c-kit, $\mathrm{MPO}$ 등이 흔 하고, 단핵모세포성 분화의 표지자로는 CD14, CD163, CD11c 가 흔하여 골수성 육종의 진단을 위해서는 이들의 양성을 확 인해야 한다. ${ }^{11)}$ 본 증례의 경우에는 $\mathrm{CD} 34, \mathrm{c}-\mathrm{kit}$ 양성 소견으 로 만능 조혈 줄기세포(pluripotent hematopoietic stem cell) 또는 전구세포 계통의 미성숙세포로 특정화할 수 있었고, 골 수성 분화의 표지자로 lysozyme, MPO 양성을 보여 골수성 육종으로 진단하였다.

감별 질환으로는 비호지킨 림프종, 유잉 육종 또는 원시신 경외배엽성 종양(primitive neuroectodermal tumor), 횡문근 육종, 신경아세포종, 감각신경모세포종(esthesioneuroblastoma), 소세포암 등이 있으며 이들 중 흔히 오진되기 쉬우며 가장 중요한 감별 질환인 비호지킨 림프종은 $\mathrm{B}$ 세포 또는 $\mathrm{T}$ 세포 계열의 종양세포군을 나타내며 이들의 표지자에는 $\mathrm{CD} 3$, $\mathrm{CD} 20, \mathrm{CD} 45 \mathrm{RO}, \mathrm{CD} 79 \mathrm{a}$ 가 있다. 따라서 골수성 육종의 진 단에서 이들의 음성을 확인해야 한다. ${ }^{8)}$ 본 증례의 경우에는 림프계 분화의 표지자로서 $\mathrm{CD} 3, \mathrm{CD} 20$ 음성 소견을 통해 림 프종을 배제하였다.

골수성 육종의 $54.3 \%$ 에서 염색체 이상 소견을 보여 세포유 전학 검사 그리고 형광동소보합법(fluorescence in situ hybridization) 검사를 통한 진단이 필요하다는 보고가 있으며, 이러한 염색체 이상에는 mixed-lineage leukemia(MLL) rearrangement, $\mathrm{t}(8 ; 21)$, monosomy 7 , trisomy 8 , MLL splitting, inv(16), trisomy 4, monosomy 16, 16q- $5 \mathrm{q}^{-}, 20 \mathrm{q}^{-}$, trisomy 11 등이 있다. ${ }^{12)}$ 하지만 이러한 유전적 이상에 따른 예 후나 치료 방법과의 연관성은 아직 밝혀지지 않아 임상적 활 용에 있어서는 더 연구되어야 한다.8)

골수성 육종은 빈도가 낮고 발생 부위가 다양하며, 연관 된 혈액 질환으로 인해 치료적 지침은 잘 정립되어 있지 않으 나 cytarabine을 포함한 전신적인 항암 치료를 일차 치료로 권하고 있다. ${ }^{13)}$ 수술적 치료는 조직학적 확진이 필요한 경우 또는 종양의 크기 증가로 인한 신경압박 등의 급성 증상이 있 을 때 시행할 수 있으며 방사선 치료는 병변이 국소적일 경우 또는 항암 치료에 실패했을 경우에 시도해 볼 수 있다. ${ }^{14)}$ 동종 조혈모세포 이식은 아직 후향적 연구가 필요하남 최근 연구 의하면 동종 조혈모세포 이식 후 5년 생존율이 $47 \%$ 이며 특 히 비강의 골수성 육종에서는 동종 조혈모세포 이식을 받지 않은 환자는 2년 이상 생존하지 못하여 효과적인 항암치료 
이후 동종 조혈모세포 이식의 필요성을 강조하였다. ${ }^{9)}$ 최근에 는 fms-like tyrosine 3 inhibitors, farnesyl-transferase inhibitors, histone deacetylase inhibitors들이 새로운 치료제 로 소개되고 있다. ${ }^{11}$

골수성 육종의 일반적인 예후는 잘 밝혀져 있지 않으나 연 관된 혈액학적 질환과 동반되어 발생하는 이차성 골수성 육 종이 원발성 골수성 육종보다 예후가 불량하며 원발성 골수 성 육종 또한 대부분 평균 1년 내에 급성 골수성 백혈병으로 진행하며 이 경우 1 년 미만으로 생존하였다. ${ }^{15)}$ 본 증례의 경우 도 이차성 골수성 육종으로 진단 후 1 개월 내 사망하였다.

본 증례는 골수이형성 증후군과 연관되어 발생한 비강의 이차성 골수성 육종의 매우 드문 사례로, 연관된 혈액학적 질 환과 함께 급격히 악화되는 특성 및 흔히 악성 림프종으로 오 진되어 치료가 늦어지는 점을 고려하였을 때 보다 나은 예후 를 위해 빠른 진단 및 치료가 필요하다. 이를 위해서는 우선 감별 진단으로 인지하는 것이 중요하며 정확한 진단을 위해 서 조직병리 검사, 면역조직화학 검사, 골수 검사가 필수적이 며 확진 후 신속한 전신적인 항암화학요법을 시작해야 하며 추가적으로 수술적 치료, 방사선 치료, 동종 조혈모세포 이식 등을 선택할 수 있다.

\section{Author Contribution}

Conceptualization: Seong Kook Park. Data curation: Dong Hoo Lee. Formal analysis: Dong Hoo Lee. Investigation: Dong Hoo Lee. Methodology: Seong Kook Park, Dong Hoo Lee. Project administration: Seong Kook Park, Dong Hoo Lee. Resources: Sung Yool Park, Ha Young Park. Software: Sung Yool Park. Supervision: Seong Kook Park. Validation: Dong Hoo Lee. Visualization: Dong Hoo Lee. Writing — original draft: Dong Hoo Lee. Writing—review $\&$ editing: Seong Kook Park.

\section{ORCID}

Seong Kook Park https://orcid.org/0000-0003-3903-8412

\section{REFERENCES}

1) Gupta AJ, Mandal S, Gupta R, Khurana N, Gulati A. Myeloid sarcoma presenting as nasal and orbital mass: An initial manifestation of an acute myeloid leukaemia. J Clin Diagn Res 2017;11(7):ED24-6.

2) Siraj F, Kaur M, Dalal V, Khanna A, Khan AA. Myeloid sarcoma: A report of four cases at unusual sites. Ger Med Sci 2017;15:Doc03.

3) Yeon WK, Kang SB. A case of myeloid sarcoma in nasal cavity after infliximab and azathioprine combo therapy in Crohn's disease. Inflamm Bowel Dis 2014;20 suppl 1:S30-1.

4) Lee JY, Chung H, Cho H, Jang JE, Kim Y, Kim SJ, et al. Clinical characteristics and treatment outcomes of isolated myeloid sarcoma without bone marrow involvement: A single-institution experience. Blood Res 2017;52(3):184-92.

5) Hwang JI, Kim TY. Primary granulocytic sarcoma of the face. Ann Dermatol 2011;23(Suppl 2):S214-7.

6) Pileri SA, Orazi A, Falini B. Myeloid sarcoma. In: Swerdlow SH, Campo E, Harris NL, Jaffe ES, Pileri SA, Stein H, Thiele J, Vardiman JW, editors. WHO Classification of Tumours of Haematopoietic and Lymphoid Tissues. 4th ed. Lyon, France: IARC;2008. p.140-1.

7) Stefanidakis M, Karjalainen K, Jaalouk DE, Gahmberg CG, O'Brien S, Pasqualini R, et al. Role of leukemia cell invadosome in extramedullary infiltration. Blood 2009;114(14):3008-17.

8) Young CK, Fang TJ, Yushin-Hung, Chuang WY, Lee TJ. Isolated myeloid sarcoma of the maxillary sinus: A case report and review of literature. J Cytol Histol 2014;5(3):234.

9) Suzuki J, Harazaki Y, Morita S, Kaga Y, Nomura K, Sugawara M, et al. Myeloid sarcoma of the paranasal sinuses in a patient with acute myeloid leukemia. Tohoku J Exp Med 2018;246(2):141-6.

10) Noh BW, Park SW, Chun JE, Kim JH, Kim HJ, Lim MK. Granulocytic sarcoma in the head and neck: CT and MR imaging findings. Clin Exp Otorhinolaryngol 2009;2(2):66-71.

11) Avni B, Koren-Michowitz M. Myeloid sarcoma: Current approach and therapeutic options. Ther Adv Hematol 2011;2(5):309-16.

12) Pileri SA, Ascani S, Cox MC, Campidelli C, Bacci F, Piccioli M, et al. Myeloid sarcoma: Clinico-pathologic, phenotypic and cytogenetic analysis of 92 adult patients. Leukemia 2007;21(2):340-50.

13) Lan TY, Lin DT, Tien HF, Yang RS, Chen CY, Wu K. Prognostic factors of treatment outcome in patients with granulocytic sarcoma. Acta Haematol 2009;122(4):238-46.

14) Tsimberidou AM, Kantarjian HM, Estey E, Cortes JE, Verstovsek $\mathrm{S}$, Faderl S, et al. Outcome in patients with nonleukemic granulocytic sarcoma treated with chemotherapy with or without radiotherapy. Leukemia 2003;17(6):1100-3.

15) Tsimberidou AM, Kantarjian HM, Wen S, Keating MJ, O'Brien S, Brandt M, et al. Myeloid sarcoma is associated with superior eventfree survival and overall survival compared with acute myeloid leukemia. Cancer 2008;113(6):1370-8. 